\title{
All Education for Some? International Development and Shadow Education in Cambodia
}

\begin{abstract}
This article compares two UNESCO reports on educational development in Cambodia, one from 1955 and the other from 2010. Although the educational problems facing Cambodia were similar in both reports, the recommendations differed in important ways, highlighting norms of different global education agendas. Whereas the 1955 report recommended the country slowly expand access to education in order to maintain quality, the 2010 report recommended quickly expanding access to education without recognizing pressures this could have on quality. Growing a system quickly reveals one major difference between the reports: school fees, which did not appear in 1955 but did in 2010. School fees in Cambodia are typically extracted through the system of private tutoring, known in the academic literature as shadow education. Such an insight, this article argues, suggests that the difference in development approach captured by the two reports is one of the reasons shadow education has flourished in the country.
\end{abstract}

Keywords: Shadow Education, Cambodia, Educational Development Compulsory Schooling, Partnerships, Privatization.

\section{Introduction}

The historical trajectory of the right to education emerged from the Universal Declaration of Human Rights in 1948 and underwent a few transitions in the last half-century. One transition occurred in 1990 when the right to education, which was previously described in various Conventions and Covenants as being both compulsory and fee-free, emerged from the World Conference on Education for All (EFA) in Jomtien, Thailand as only compulsory (Bray \& Kwo, 2013). The commitment to make basic education fee-free waned as the international community realized some nation-states, particularly developing ones, could not bear the high-costs of schooling.

The notion that governments could not pay the costs of public schooling for all children ushered in an era of partnerships and privatization. Schooling costs would now be paid by - or split among - institutions and international donors beyond national governments. The private sector was relied upon as well, often extracting profit in various ways (Adamson, Astrand, \& Darling-Hammond, 2016). Discursively, the concept of "partnerships" captured this new arrangement (see UNESCO, 1990, pp. 10-12) and terms such as "public-private partnerships" became commonplace (Robertson, Mundy, Verger, \& Menashy, 2012). Although the idea of governments ensuring feefree education reappeared in the 2000 Millennium Development Goals (MDGs) as well as the 2015 Sustainable Development Goals (SDGs), partnerships and privatization that share with governments the costs of schooling have remained as a mechanism to reduce the education financing gap worldwide (see, e.g., Menashy, 2019). The global education agenda, captured today by the SDGs, aims for "all girls and boys complete free primary and secondary schooling by 2030" 
(SDG Goal 4). The goal relies on partnerships to help governments achieve universal education. As Klees argued, "the principal problem is lack of resources. Although domestic taxation in developing countries can finance over $90 \%$ of what is required to give a quality primary and secondary education to all children, (Archer, 2016), there is a significant shortfall that must be financed by international aid - about US $\$ 40$ bn in 2020, reaching US $\$ 90$ bn by 2030 " (Ron Balsera, Klees, \& Archer, 2018, p. 149). Although these authors raise concerns about tax justice and progressive tax systems, few development organizations share this priority.

Missing from this focus on financial "partnerships" (with the private sector, civil society organizations, and/or bi/multi-lateral donors), however, is another cost-sharing arrangement that has become commonplace in the post-EFA era, albeit often implicit and hidden from domestic and international policymakers: private supplementary tutoring, known broadly as "shadow education" (e.g., Bray 1999a), which is typically paid not by communities but by households directly to schools and/or teachers. It is this latter phenomenon, which too can be thought of as a form of "partnership," that is explored in this article. ${ }^{1}$

Given that "partnerships" appeared in the global education framework starting in 1990, a historical comparison of the international education development agenda before EFA can help illuminate some of the reasons why shadow education emerged in the first place. In many ways, shadow education is an unintended consequence - or "side effect" to expand Yong Zhao's (2018) conceptof development efforts advocating partnerships: the signatories and technical teams who drafted the Framework for Action to meet EFA likely did not imagine that private tutoring would be used as a way for communities - and specifically families - to "mobilize additional financial and human resources where necessary" (UNESCO, 1990, p. 11) in ways that advanced the benefit of one's own children over others, a form of inequality produced through public systems of schooling. Moreover, recent efforts to regulate private involvement in public education through mechanisms such as the Abidjan Principles (2019) fail to recognize the prevalence of shadow education. Whereas the Abidjan Principles recognize and aim to regulate private institutions in efforts to "realise the right to education for all by providing free, inclusive, quality, public education" (p. 4), shadow education in many countries happens in more informal manners, between students and teachers, some of whom work for public, private, or both types of institutions. The complexity inherent in concept of shadow education is absent in the Abidjan Principles, which differentiates between - and therefore dichotomizes - public and private. That even the most recent efforts aimed at protecting and fulfilling the right to education neglect shadow education suggest it is an important topic to explore vis-à-vis the global education agenda.

The case of Cambodia is a useful starting point in such a historical comparison because the country witnessed international education development efforts when it became independent in 1953, only

\footnotetext{
${ }^{1}$ Such a partnership could be considered as a household-to-government partnership whereby households end up paying various fees for the cost of education that governments cannot. This is another way of describing a tax; however, the phenomenon of private tutoring is regressive since rarely do household contributions get redistributed in an equitable way. Rich children typically receive more and better tutoring than poor children.
} 
five years after the signing of the Universal Declaration of Human Rights. Between 1970 and 1991, civil unrest eliminated most of the international development efforts implemented by Western countries in the previous decade and a half. Only after the Paris Peace Agreements were signed in 1991, did international development begin anew, right after the EFA conference. This means that Cambodia was like a blank slate on which development efforts in two distinct periods were written, making for a valuable comparison. The 1990s also happens to be when the phenomenon of private tutoring begins to be empirically researched in Cambodia, allowing for a robust understanding of the phenomenon.

This article is based on a discourse analysis of two UNESCO reports, one from 1955, written by Charles Bilodeau, and one from 2010, produced by the Education Unit of UNESCO's Phnom Penh office. $^{2}$ The UNESCO reports were particularly chosen in the analysis. Given the fact that the Cambodian government took the responsibility of the Ministry of Education in 1946 (UNESCO, 1955), joined UNESCO in July 1951, and Cambodia gained its independence in 1953, the report of 1955 provides deeper insight into the educational development in post-colonial, independent Cambodia. By contrast, the UNESCO report of 2010, which presents educational development in the post-political unrest period in Cambodia, captures the turn towards "partnerships" started in the 1990s.

Through examining these reports, a comparison of the educational development efforts at these two distinct time periods offers valuable insights into the continuities, discontinuities, and emergent trends in achieving universal and fee-free education vis-à-vis shadow education. Ultimately the idea of "partnership" is expanded to include payments by individual students to schools and/or teachers. The historical comparison reveals that the main thrust for educational development in Cambodia in both periods was a focus on increasing access to education, often times in lieu of quality; however, certain differences exist: until like the $1950 \mathrm{~s}$, the $21^{\text {st }}$ century was marked by pervasive private supplementary tutoring, causing serious implications for equity and quality education.

\section{Background}

The case of Cambodia highlights the tension among a state's financial constraints, the prevalence of shadow education, and achieving the global goal of universal education. Achieving universal education, although the main pillar of international education development efforts, has a legacy in Cambodia dating as far back as a 1911 decree signed by King Sisowath. During this time, contributions from villagers were instrumental in financing education, often as gifts to teachers in the form of food, money, or both (Bray, 1999b). Despite this long history, it was only after independence from France in 1953 that compulsory, universal, and fee-free education became a priority of the government. From the post-independence era of the early 1950s until the early and mid-1970s, there was significant progress in the Cambodian education system (Bray, 1999b). During this period, the country experienced an increase in its education budget, which led to a relative increase in teacher salary (Bray, 1999b). Although state schools were prioritized,

\footnotetext{
${ }^{2}$ For simplicity, we refer to these reports as UNESCO (1955) and UNESCO (2010).
} 
modernized pagoda schools were also part of the Cambodian education system (Bray, 1999b). Furthermore, villagers provided construction assistance (Bray, 1999b; see also Ayres, 1997, p. 69). Educational reforms in the in the 1950s and 1960s were not limited to development in educational infrastructure, there were also curricular reforms aiming for instilling 'Khmer character' (Clayton, 2005; see also Whitaker, 1973, p. 42). Dunnett (1993) argues that "during the 1960s, Cambodia had one of the highest literacy rates and most progressive education systems in Southeast Asia" (as cited in Dy, 2004, p. 94). Notwithstanding these noteworthy attempts to improve the education in Cambodia, the educational development efforts by the national and international community made in the 1950s and 1960s were, however, quickly erased by the geopolitical and civil unrest that engulfed many countries in Southeast Asia in the 1970s. By the 1990s, after two decades of war, civil conflict, and international isolation, Cambodia stabilized politically and economically, and renewed its efforts at educational development, this time in line with the EFA and MDG goals, which were promulgated contemporaneously with the country's so-called re-emergence. ${ }^{3}$ This section briefly details important background of the international education development agenda in Cambodia in two periods, pre-1990 and post-1990.

\subsection{Cambodia Pre-1990: The emergence of modern schools}

Education in Cambodia has historically been organized through Buddhist pagodas where memorization and rote learning were common pedagogical features (Reimer, 2012, see p. 180). Modernization efforts to change monastic education in Cambodia away from "so-called traditionalists" (Kobayashi, 2005) began in the early 1900s by a group of Khmer monks, led by Chuon Nath and Huot That. Hansen (2011) found that these monks "opposed older methods of learning that featured rote memorization and urged religious people to accurately understand each word of scripture and to ensure that rituals were authentically performed, according to scriptural injunctions" (p. 40). At this point in time, public schooling like that in the West did not exist.

Domestic modernization efforts to reform monastic education dovetailed with French colonial efforts at introducing the Western conception of public schooling. Although French colonialism began in Cambodia in $1863,{ }^{4}$ it was not until the 1900 s when public schools first appeared. This occurred through the work of French colonial scholars of Indochina who helped reform the Cambodian system of pagoda schools in the second decade of the $20^{\text {th }}$ century. These scholars also emphasized pedagogical practices other than memorization. Unlike the Khmer monks who believed that modern pedagogies should be used to overcome the moral degeneration they saw in society, French scholars justified the reforms using notions of rationality and the scientific method. Despite different intentions, they shared a common reform agenda.

The shared interests between modernist monks and French colonial officials ushered in an expansion of modern schooling. By the 1920s, some 10,000 children attended modern primary

\footnotetext{
${ }^{3}$ During the period of civil unrest between 1970 and 1990, Cambodia was recognized and supported by the Soviet Union. The country's "re-emergence" was from the perspective of the international community aligned with the United States, what is referred to here as "the West."

${ }^{4}$ Cambodia was technically a protectorate of France.
} 
schools. By 1944, over 80,000 did so (Kiernan, 1985). In the 1950s and 1960s, King Sihanouk accelerated educational reforms, building schools and hiring teachers which ultimately increased the number of children attending school:

By the late 1960s, more than one million children enrolled in primary education as compared with about 0.6 million in 1960 and 0.13 million in 1950. From 1950 to 1965 the number of females enrolled at the primary level grew from 9 per cent to 39 percent. The number of teachers and schools has expanded commensurately from 1950 to 1964. (Deighton, 1971 p. 579)

By the 1960s, the government was spending over 20 percent of its recurrent budget on education, far larger than proportions in the 1990s and 2000s (Dy, 2004; see also Brehm, Silova, \& Tuot, 2012). The focus on access was reiterated in an overall assessment of the educational developments efforts between 1950 and 1970:

To what extent did this increase [in access to schooling between the 1950s and 1970s] meet the needs of the country? Education had certainly been neglected, and after independence some degree of rapid development was desirable and laudable. The attitude of Cambodians, however, seemed to be that the maximum amount of modern education in any field at all for the maximum number of children was an absolute good in itself, without ever taking into account the absorptive capacities of the society. (Vickery, 1984 cited in Fergusson \& Masson, 1997, p. 100)

Despite the educational reforms that brought more children into schools, many problems remained. Schools were mainly located in urban centers; the illiteracy rate was not declining; and employment opportunities for graduates were rare (Ayres, 1999; Chandler, 1991; Duggan, 1996). May Ebihara, the first American anthropologist to do field work in Cambodia starting in 1959 and who has had outsized influence on the English-language scholarship ever since (see Marston, 2011), wrote about the new schooling environment she witnessed in unflattering terms: "It is uncertain, however, as to whether a very large percentage of the peasantry (especially women) were able to take advantage of this augmentation in education" (1968, p. 47).

The biggest issue facing schools was the quality of instruction. Monastic education legacies of memorization and rote learning persisted. In the 1950s, reservations existed that were similar to the ones levied on the traditional form of monastic teaching by the pro-modernization monks and colonial administrators in 1918 (Hansen, 2007, pp. 136-137). The 1955 UNESCO, for instance, observed:

[Pupils] learnt to read the [Buddhist] sacred texts...and copied out the written characters. In actual fact, the texts were learnt by heart, as a result of endless repetition, and the pupils were quite incapable of reading the words separately. A Cambodian boy leaving the pagoda school had his memory stocked with edifying passages, but could neither read, write nor count. (UNESCO, 1955, p. 21) 
Efforts to reform pedagogical practices in the name of modernization between the 1900s and the 1960s failed to take hold. More students than ever enrolled in schools, but rote learning persisted despite the various development efforts. The development efforts during and just after colonialism were all but erased by 1975 when the Khmer Rouge came to power, eliminating all Western influence in the country. There is not space in this article to detail the educational policies and legacies of the Khmer Rouge and during the 1980s (see Ayres, 2000). Suffice it to say, schools were closed and educated citizens were targeted in the killings. In the 1980s, the educational policies primarily followed the Soviet Union and Vietnam, as Cambodia was isolated from the Western international community as part of Cold War geo-politics (Clayton, 2000; Hagai, et al., 2016). Importantly, when examining the historical record before the 1990s, there is no recognition that private tutoring existed. It is this phenomenon that we turn to next in the 1990s, when western development efforts were allowed back into the country.

\subsection{Cambodia Post-1990: The emergence of private tutoring}

The call for EFA found a privileged policy space (becoming guaranteed in the constitution) inside Cambodia since the October 1991 signing of the Paris Peace Agreements. Part of the Agreements placed the Cambodian government under the control of the United Nations Transitional Authority of Cambodia (UNTAC). Under the supervision of UNTACT, the push for compulsory education returned, this time in line with development trends of the era. In many ways, establishing schools was a necessary step for a war-torn country. However, the country slipped back into political unrest after the UNTAC backed elections in 1993, which produced a dual prime ministership and a political environment whereby the Khmer Rouge, which still maintained control in parts of the country, were able to further the political turmoil. ${ }^{5}$ The actual adoption of an EFA policy was all but delayed beyond a 1995 assessment.

As national politics caused unease both to domestic policymakers and the international community at large, many donors withheld pledged development aid until the turmoil was resolved (Brinkley, 2011). This resolve came after the 1998 elections when the Cambodian People's Party won enough seats in parliament to form a majority government. Soon thereafter, international development agencies such as the World Bank recognized Cambodia once again and began lending programs. Cambodia experienced a period of relative peace as the new millennium approached, and - in such an environment - education policies were quickly written and approved, this time in terms of the new United Nations development initiative, the MDGs. The MDGs through Goal 2 connected to the 1990 EFA initiative and re-introduced the notion of fee-free education while codifying the idea of partnerships in Goal 8. Of the first policies adopted by the Cambodian Ministry of Education, Youth, and Sport (MoEYS) were the Education for All 2000 Assessment, which was a follow up to the 1995 assessment and eventually turned into the Education for All National Plan (MoEYS,

\footnotetext{
${ }^{5}$ Democratic Kampuchea, known as the Coalition Government of Democratic Kampuchea after 1982, continued to be considered the legitimate government of Cambodia as recognized by the United Nations until 1993, when the Kingdom of Cambodia was finally established. This political history provided support internationally and nationally through the 1990s. For a further discussion of the political events in the 1970s and 1980s, see Michael Haas (1991a, 1991b).
} 
2003), and the Cambodian Millennium Development Goals policy, both written for the 2003-2015 period.

These policies were the keystone to Cambodian educational development until the SDGs were adopted in 2015. Targets were set to achieve, among others, a primary school repetition rate of 10 percent or less; primary school dropout rate of 5 percent or less; primary school completion rate of 70 percent or more; and a primary net enrolment rate of 80 percent or more (MoEYS, 2003). The logic behind the EFA plan was to "to reduce the cost barriers on access to high quality basic education for all through a combination of systemic developments (e.g. abolition of informal payments) and a number of poverty targeted interventions (e.g. incentives for the poor, ethnic minority groups and girls to attend school)" (MoEYS, 2003 p. 19). The targets overwhelmingly focused on access to education and were, to some extent, achieved by 2010 (UNESCO, 2010; Engel, 2011). In 2007-2008, for example, the net enrollment rate at the primary level was 92.7 percent in urban areas (UNESCO, 2010), well above the 80 percent target. Further areas needed to achieve universal access to education were identified with the help of organizations such as UNESCO and a revised plan was drafted for the remaining years of the 2015 target date.

It was during the 1990s that a system of private tutoring first emerged, causing inequality among students (Marshall \& Fukao, 2019). As more students enrolled and double shift schooling became commonplace in the 1990s, the International Development Banks persuaded the government to reduce education expenditures (Benveniste, Marshall, \& Araujo, 2008; Brehm et al., 2012). As a result, a private system of schooling emerged to meet the increased demand for education that could not be met by an under-funded public system of education.

A main feature of this new educational arrangement was private tutoring. Private tutoring takes many forms (Brehm, 2017). The most common form of tutoring is "regular private tutoring" (rian kuə thoəmmada:), which is fee-based tutoring in classes taught by public-school teachers. It is "regular" (thoəmmada:) because it focuses on the mainstream curriculum and the class sizes and layouts are similar to public school. Another form is "special private tutoring" (rian kuə piseh), which covers individual or small group classes taught by a tutor who may or may not be a student's public-school teacher. These classes cost more than regular private tutoring classes. In addition, some students have the option of attending and paying for "private tutoring during holidays" (rizn kuə pe:l vihsa?ma?ka:l). These are classes conducted in school or at a teacher's home and are held by a student's current or future teacher when public-school is not in session. The last type of private tutoring is "private tutoring at private school" (rizn kue nim sa:la: aekəcven or sa:la: kuə). This type of private tutoring covers tutoring classes of various sorts, held by non-mainstream school teachers outside public school buildings, and for some cost. The word "school" in this type of tutoring takes on a broad meaning from registered tutoring centers as businesses to make-shift classrooms inside university students' homes or apartments. More recently, online tutoring has emerged to offer students with smartphones or computers examination preparation.

The scale and scope of private tutoring in Cambodia has been well-documented (e.g., Bray 1996, 1999a; Bray, Kobakhidze, Zhang, \& Liu, 2018). In a study of 444 students in six schools in one province, 68.4 percent of grade 9 and 41.3 percent of grade 6 students attended regular private 
tutoring (Brehm, et al., 2012, p. 22). Data for grade 6 students were 10 percent higher than a 1999 study (Bray, 1999b) of 77 primary schools, and similar to a 2011 survey of eight primary schools in three locations (Dawson, 2011). Overall, private tutoring in Cambodia has been recognized by scholars as a leading cause of educational inequality in the post-1990 era (Bray, Liu, Zhang, \& Kobakhidze, 2019). A closer look at the UNESCO reports between these two moments offers additional insight into why tutoring emerged in the first place, and challenges development efforts to recognize the complexity of partnerships and privatization in Cambodian education system (and beyond).

\section{Findings}

The UNESCO reports of 1955 and 2010 are telling documents of Cambodia's continuous development problems. Ten years before 1955, Cambodia was undergoing a transition from French rule as part of the geopolitical consequences of World War II. By 1955 in post-colonial Cambodia, enough years had passed since the political upheaval (resulting in a new King, Norodom Sihanouk) to gauge the budding system of education and provide a clear strategy forward, as the report does. Likewise, in 2010, over ten years had passed since the last political unrest (the 1998 elections) reverberated through the country after nearly 30 years of genocide, civil war, and geopolitical neglect (Chandler, 2008). By 2010 in post-UNTAC Cambodia, education reforms had been in effect for nearly 10 years. To a certain degree, each of these time periods represents a transition period in Cambodia's history, away from times of conflict and towards a post-conflict society. It is not surprising, therefore, that many of the education problems outlined in 1955 are reiterated in 2010 (see table 1). Issues like few teachers, inadequate funding, and limited resources (although updated in technical terms, for example, from "chalk" to "computers") affected both post-conflict and transitional systems of education. The destruction of an educational system (as in the post-UNTAC era) or the infancy of an educational system (as in the post-French colonial era) required returning to the basic building blocks of an educational system: more students, buildings, books, and teachers. What is important, however, is the difference in prescriptions offered to remedy the underdeveloped education systems at each period. In the next two subsections, a look at the differences in terms of system management and expanding access are explored in more depth. These two differences provide important insight into the phenomenon of shadow education.

\begin{tabular}{|c|c|c|}
\hline$\underline{\text { Educational Problem }}$ & UNESCO, 1955 & $\underline{\text { UNESCO, } 2010}$ \\
\hline Too few teachers & $\begin{array}{l}\text { "The shortage of trained teachers } \\
\text { has likewise impeded the spread of } \\
\text { education. In each of their annual } \\
\text { reports, the educational authorities } \\
\text { have invariably deplored the } \\
\text { scarcity of certificated primary } \\
\text { teachers and the poor quality of } \\
\text { the others" (p. 19). }\end{array}$ & $\begin{array}{l}\text { "There are not enough } \\
\text { teachers at all levels- } \\
\text { particularly in the remote } \\
\text { and rural areas" (p. 25). }\end{array}$ \\
\hline
\end{tabular}


"Between 2004 and 2006,

"Usually a master is responsible for a large class, the school premises are inadequate, and there is a shortage of every kind of

\section{Too few learning} materials

Financing issues

Limited pedagogy

Class size too big educational equipment; sometimes he even has to use his own money to buy chalk, books, and maps." (p. 41)

"In addition, the economic backwardness of the country meant that little money could be spared for education... The quality of the teaching is bound to suffer from the lack of textbooks, maps, wall charts and demonstration material. The authorities will doubtless be anxious to satisfy these needs as a matter of priority, and the help of international organizations might well be sought in order to fill the gaps" (pp. 20, 46).

“...the texts were learnt by heart, as a result of endless repetition, and the pupils were quite incapable of reading the words separately" (p. 21).

"Classes are large; some comprise as many as 60,80 and even 100 pupils, the average being 48 for the elementary cycle" (p. 29).
UNESCO also facilitated the donation of hundreds of used laptops and desktops.

UNESCO also provided 33 new desktop servers to different teacher training colleges as well as 637 educational CD-ROMs, DVDs and VCDs to 51 educational institutions across the country" (p. 50).

"Cambodia is still quite dependent on international aid which comprises approximately one-third of the national budget... The total budget projected for the education sector for 2007 2011 is USD \$430 million. Of this amount, $1.72 \%$ is from national budget, $77.46 \%$ from international grants, $20.77 \%$ from loans, and $0.05 \%$ from local support" (pp. 35-36).

"One concern is the highly academic nature of the teacher training curriculum. A large proportion of the time is spent on academic upgrading as opposed to teaching methodology and in-school teaching practices" (p. 26).

Primary pupil teacher ratio: 53.3:1 in 2000-2001; 50.8:1 in 2005-06; and 49.3:1 in 2007-2008 (table on p. 23).

\subsection{System Management}


In 1955, the recommended approach to develop education was based on a slow, managed growth of compulsory education while at the same time emphasizing the quality and financial constraints of the system. For example, the 1955 report points out that "the shortage of trained teachers has likewise impeded the spread of education. In each of their annual reports, the educational authorities have invariably deplored the scarcity of certificated primary teachers and the poor quality of the others" (p. 19). As the quote implies, authorities aimed for ensuring the quality of education while forming policies concerning the spread of education. It must be remembered that in 1955, the common discourse within UNESCO was that education should be universal, compulsory, and fee-free, meaning that success would only be achieved if the government could meet the needs of all students to attend school. In 1955, the authors wrote:

Compulsory schooling cannot be suddenly imposed; it must be prepared several years in advance. Good progress in this direction has been made since the end of the war [WWII]. If the rate of increase recorded in the last few years is maintained, all children will be attending school in 10 or 12 years' time. It is the moral duty of the state, before making education compulsory, to offer the pupils proper schools with hygienic conditions, qualified teachers and a suitable curriculum. School must become a sufficiently attractive place for the children to want to attend of their own accord. Compulsory education then does no more than set its seal on an already existing situation, and the element of compulsion is aimed at only a small number of recalcitrants. (UNESCO, 1955, p. 31)

Acknowledging that the infrastructure and system of education were relatively new to Cambodia, the 1955 report recommended that the Cambodian government build off of the "already existing situation" left by the French to slowly move to a compulsory system of modern education. The 2010, by contrast, report all but removes issues of quality, supporting instead "inclusive education" that will achieve the MDGs and EFA initiatives and highlighting the problems of informal fees in schools. For example, the report states:

Cambodia has made considerable progress in some key MDG-related indicators and could meet its target for universal primary enrolment. However, meeting its target for secondary education, female enrolment rate and school completion rate seem unlikely. Much remains to be done to improve the quality and affordability of education. (UNESCO, 2010, p. 17)

In the appendix, the 2010 report (p. 59) continues to focus on expanding access while only briefly mentioning issues related to quality

Cambodia is likely to reach its target of $100 \%$ enrolment ratio before 2010 . However, the quality of education is still low. Although Cambodia is on track with its goal of universal primary education, the enrolment ratio in lower-secondary education is only 19 percent. The main challenges include ensuring equitable access to basic education, increasing budgetary allocation, subsidizing transportation and scholarship to target students from poor families, and improving the quality and efficiency of the teaching system. 
A revealing comparison of the commitment to access during these two time periods can be found in the UNESCO recommendations and how the government responded legally and constitutionally to compulsory education. In post-colonial Cambodia, UNESCO recommended:

For the immediate future, no advantage would be gained by adopting, like other countries, a law for compulsory education which would remain a dead letter and in regard to which the state itself could not discharge the responsibilities incumbent upon it. (UNESCO, 1955, p. 35)

Likewise, the same UNESCO report also stated:

It is the ambition of the Cambodian Government to ensure that all children shall be given a certain minimum of education, and it therefore wishes to introduce a system of compulsory education. A laudable ambition, indeed; but in view of the many thousands of children still not on the register of any school, it would be Utopian to attempt enforcing such a system immediately. (UNESCO, 1955, p. 30)

Indeed, as early as 1951 the government of Cambodia used a similar refrain. At the UNESCO Conference on Public Education, Cambodian Princess Ping Peang Yukanthor stated:

The principle of compulsory education can thus not be fully applied - until the government is in a position to fulfill its essential duties through the possession of sufficient number of teachers able, not only to instruct, but also to educate, and of adequate funds to meet all necessary expenditures (cited in Dy, 2004, pp. 93-94).

In 1993, by contrast, compulsory and fee-free education were recommended by UNESCO and adopted in article 68 of the newly ratified Cambodian constitution. As a result, the logic guiding systems management policy shifted from a gradual to fast growth approach. This shift contributed to the conditions making it necessary for households to pay education expenditures. If the government could not provide quality education because too many students enrolled, then households would be left on their own to do so, something Verger, Novelli and Altinyelken (2012) have called "de-facto privatization" in other contexts. In Cambodia, de-facto privatization is the many forms of private tutoring previously described. The over-emphasis of access to education without a recognition of the system's limitation offer additional ways of understanding the emergence of the private tutoring system not simply as a way to increase teacher salaries due to an under-funded education system (Dawson, 2009) but also as a way to fill the quality gap in public education that results from too many children in school and a curriculum perceived to be too "full" to complete within the allotted time (Brehm et al., 2012; see also Edwards, Le, \& Sustarsic, 2019).

The system management approach also differed between the reports in terms of the emphasis given to the Cambodian context versus international norms. The 1955 UNESCO report clearly recognized Cambodia as being different than many countries in the West: 
The entire body of knowledge and habits to be instilled into children during their primary school years must be reconsidered in the light of existing conditions in Cambodia itself. The final curriculum is thus bound to differ appreciably from that of Western countries (UNESCO, 1955, p. 49).

This recognition echoes the finding of other scholars who have studied the education system in the post-independence era. Clayton (2005), for instance, found that the curriculum at the time replaced French colonial influences with Khmer national "culture, civic and moral instruction, the geography of Cambodia and its neighbors, and the history of Asia" (p. 506). Whitaker (1973, p. 42) argued that the curriculum tried to instill a "Khmer character" in students, rather than the colonial mentality. In general, it seems clear that the 1950s and 1960s emphasized the domestic context of educational reforms.

In 2010, by contrast, there was little focus on creating a curriculum based on the realities of lived experiences of Cambodian people. Instead, the goal was squarely situated on the international norm of increasing access to education. The term used in 2010 was "Inclusive Education," which refers to the "hard-to-reach" children that constituted the last few percentages of the population not currently enrolled in primary school. Even when quality of education was mentioned, the report referred to the Child Friendly Schools (CFS) modalities, another United Nations sponsored framework (developed by UNICEF) that bases educational management on human rights (MoEYS, 2007). Moreover, the 2010 report addressed the issue of quality by offering vague suggestions of "enhancing quality basic education through the improvement of ICT [information computer technology] in education, curriculum development, and teacher education" (p. 52), without offering details or recognizing the fact that many schools in Cambodia do not have access to electricity. Instead the report points to the CFS framework adopted by the MoEYS in 2007. Although there is not space in this paper to explore in depth the issues of quality as addressed in the CFS framework, it is worthwhile to point out that the first goal of the CFS model deals exclusively with access: "All children have access to schooling."

In summary, when comparing the 2010 report with the 1955 report, there appears to be a shift in the recommended approach towards system management. The 1955 reported recommended a slow, managed growth of compulsory education, only expanding as quickly as the other components of the education system (teachers, schools, etc.) are established. It also recognized and embraced the cultural context of the country. By contrast, the 2010 report advocates what we call "a fast growth model": the goal is to achieve the target of universal education for all groups in all grades, making quality education a secondary issue. Admittedly, the 2010 report draws attention to the problems of teacher education, which impacts the quality of education in Cambodia. However, it prioritizes increasing the enrolment rate in education despite recognizing some of the main constraints to quality. Finally, the recommendations in 2010 follow international norms, neglecting (at least discursively) the Cambodian context.

\subsection{Financial issues}


A major difference between the two reports concerns education expenditures, which have a direct effect on informal fees to education and the need for development partnerships. During the 1950s, government annual expenditures on education were reported to be over 20 percent of the total government budget (Dy, 2004). Although the 1955 report stated "help of international organizations might well be sought in order to fill the gaps" in providing classroom materials (pp. 20, 46), education was found to be free "at all levels":

Entrance fees have never been asked for, textbooks have always been provided free of charge (this benefit has often been extended to other school equipment as well), and many resident scholarships and various allowances have been awarded. This practice does great credit to the country's authorities, and merits continuation. (UNESCO, 1955, p. 37)

Such a description is absent in the 2010 report. As more children enrolled in school under the fast growth model during the post-1990 period, government expenditures were stressed to meet the needs of the system. This is not surprising since education budgets in the 2000s never reached previous levels (at least until 2018). In 2008, for instance, the education budget was under 18 percent (Benveniste et al., 2008). By 2012, the expenditures were below 16 percent (see figure 1). Making matters worse, researchers (European Commission, 2012) have found in 2006 that the budgeted expenditures on education have typically been higher than the actual expenditures. This means less money is spent on education than budgeted. The World Bank online data reports of expenditures on education as a percent of Gross Domestic Product (GDP) have ranged from 1.2 percent in 1998 to 1.9 percent in 2014, far below the recommended amount of 6 percent of GDP (Ron Balsera, Klees, \& Archer, 2018).

\section{Figure 1. MoEYS Budgeted and Actual Recurrent Expenditures}

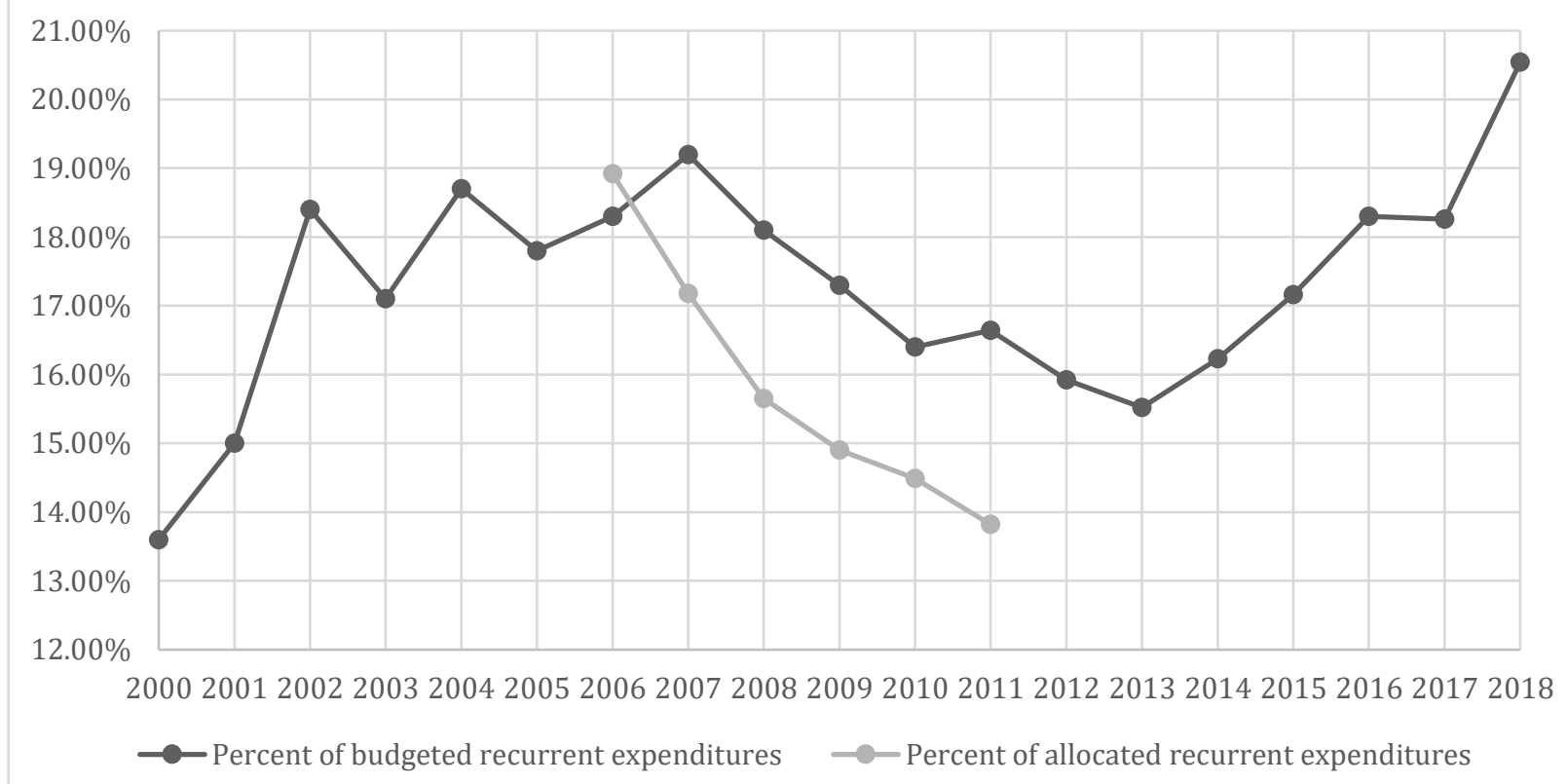

Source: Authors compiled data 
In the post-1990 era, Cambodia regularly sought partnerships to meet the financial needs of its growing education system. The 2010 report stated that the country "seeks financial cooperation with development partners to support its national development goals" (p. 15) because it recognized that although "the amount of money allocated to education is rising, education financing as a percentage of GDP is decreasing" (p. 20). Indeed, the 2010 report highlighted that education expenditures were overwhelmingly paid for by international grants and loans (see p. 36). International grants and loans accounted for 98.23 percent of the education budget between 2007 and 2011. Partnerships with civil society, private industry, and international development agencies are meant to cover a range of issues and sub-sectors, from ethnic minority education (p. 29) to technical and vocation education and training (p. 25) to higher education (p. 27). Taken together, Cambodia by 2010 was emblematic of the partnership era of the global educational agenda.

Another form of partnership that was alluded to in the 2010 report were household costs. As the number of students enrolled in education reached over 90 percent of the school-aged children, household costs to education were reported to be a burden on families. The 2010 report emphasizes "for many rural families that rely on agriculture for subsistence, education costs are the highest expense they face annually. Often they cannot afford to educate all of their children and choose only certain children to attend school" (p. 28). More specifically, the 2010 report situated fees within the larger society:

As is evident in the Cambodian society across the board, irregular practices also permeate the education system. For example, illegal fees in schools and payment for hiring, transfer and promotion affect the quality of teaching and learning. (p. 31)

These "irregular" and "illegal" practices were never elaborated. It is safe to assume, however, that the 2010 report saw the fees as stemming from Cambodian culture ("Cambodian society across the board"), not the development agenda it was advocating.

When looking at the data on household fees it becomes clear that the main cost of education by 2010 was private tutoring, something that, as will be shown below, is not "irregular" but actually an unintended consequence of the development logic post-1990. Household costs of education are admittedly difficult to collect and calculate because some costs, such as food purchased at school, would have been spent regardless of a child's attendance (see figure 2). Nevertheless, we proceed with caution by looking at overall, large trends, and do not read too greatly into any one number. Real household expenditures on primary education decreased between 1997/8 and 2007 (see figure 2), most likely because of various laws that made certain fees illegal (see Bray \& Bunly, 2005).

\footnotetext{
Figure 2: Average Yearly Household Costs of Education in Primary School (in Riel)
} 


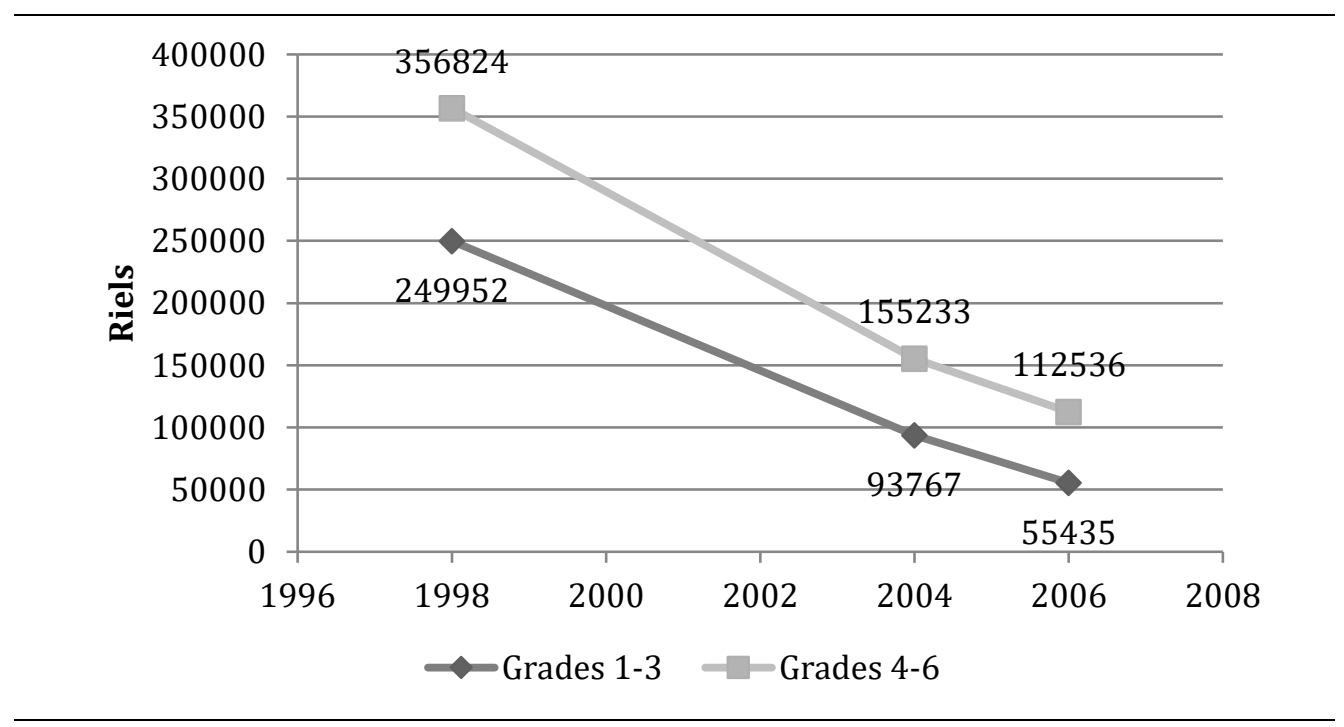

Source: Bray \& Bunly, 2005, p. 51; NEP, 2007, p. 21

However, private tutoring fees have remained and in fact increasingly constituted a large proportion of total household costs on education. A government conducted, nation-wide household survey in 1997/8 found that private tutoring, on average, constituted 1 to 19 percent (depending on socio-economic quintile) of household expenditures on education (reported in Bray \& Bunly, 2005, p. 53). By 2006, private tutoring fees made up, on average, 78 percent of total household costs to basic education in a survey of 210 households in four provinces (NEP, 2007, p. 21. Notwithstanding the differences in methodology to calculate household costs of education, previous research has found that although the total expenditures on education, which include fees other than private tutoring, have decreased since 1997/8, the fees that remain are being concentrated primarily in private tutoring. Data from NEP (2007) suggest overall household costs of education at the secondary level are more than double the average grade 4-6 level. The notion that secondary school is more expensive than primary school is logically consistent with data that showed larger numbers of students attending more hours of private tutoring at the secondary level as compared to primary level, indicating the costs would be higher (Brehm et al., 2012).

By way of summary, this difference highlights how the focus on access without increasing government expenditures on education helped create the circumstances where private tutoring was able to flourish, even if going unacknowledged in the 2010 UNESCO report. The educational development focus since the 1990s thus has created the circumstances for a system of private tutoring. Private tutoring is a form of development partnership to fund education, through which it is expected to overcome, increasing low teacher salaries and provide needed school resources.

\section{Discussion and Conclusion}

This article has attempted to show how the emphasis on increasing access to education has been articulated in different ways by UNESCO in two different historical periods. The 1955 UNESCO report recommended the Cambodian government expand access slowly in order to develop a 
system of education that it can adequately support (both educationally and financially). It called on the "moral duty of the state" (p. 31) to ensure high-quality education even if that meant leaving some children out of school while educational structures were built. International partnerships were not prioritized; rather, developing the state's capacity to manage itself was.

The 2010 report, by contrast, focused almost entirely on achieving universal access, assuming partnerships with civil society, the private sector, and donors would be needed to meet international development goals. It recommended enrolling the greatest number of children into school to act "as a catalyst to achieve national priorities on human capital development" (p. 32). Working with private industry and development partners was the answer to bridging financial and technical gaps. Notwithstanding the rhetorical shift back to fee-free schooling with the adoption of the MDGs in 2000, Cambodia appears to have continued to embrace the 1990 sentiment "that additional resources for education will have to come from private rather than public sources" (Windham, 1992, p. 80), which was discussed during the EFA World Conference. Not only did "additional resources" come from various international donors (as it continues to do so today) but also from individual domestic students who have had to pay private tutoring fees. These fees did not exist in the 1950s.

The combination of increased educational enrollment, decreased educational expenditures, and the emergence of partnerships in the development agenda post-1990 provide new ways of explaining the rise of shadow education in Cambodia, a feature common in 2010 (and perhaps as early as the 1990) but not present at all in the 1950s. As more students enrolled in school at a faster pace than quality teachers could be trained or enough classrooms could be built, double shift schooling, overcrowded classrooms, and shrinking teacher salaries became commonplace. This opened the door to the practice of private tutoring, a new form of partnership between households and schools.

To some extent, the rise of shadow education in developing countries such as Cambodia is a symptom of making education both compulsory and fee-free without reforming systems of taxation. That such a discussion on taxation is present in the 1955 report (see p. 59) but absent in the 2010 report is a telling difference between the international development priorities of the two eras. It is clearly an area that should be explored in future research.

Despite the success of enrolling large numbers of students into school and the emergence of partnerships in post-1990, education quality has been by-and-large a secondary priority. By tracing the continuities and discontinuities in Cambodian efforts as well as the recommendations by two different UNESCO reports to implement compulsory education, this paper has shown the negative consequences of the shift away from controlled growth in access to ensure quality in the 1950s towards a fast growth model to increase net enrollment rates in the post-1990 agenda. This has created a situation where quality education is nearly impossible to achieve in the overcrowded and underfunded public system of education without the use of shadow education, which is a sideeffect of partnerships never envisioned in the 1990 EFA conference. As a result of the overemphasis on access, a system of private supplementary tutoring fills the gap in education quality. The public-private system of education that has emerged starting in the 1990s is perhaps best defined not as a system of "Education for All" but rather as "All Education for Some." 


\section{References}

Abidjan Principles. (2019). Guiding principles on the human rights obligations of states to provide public education and to regulate private involvement in education. Retrieved from https://static1.squarespace.com/static/5c2d081daf2096648cc801da/t/5d5f200b80e776000 1a9143a/1566515220020/Designed_A4_WEB_Abidjan+Principles_august2019.pdf

Adamson, F., Astrand, B., \& Darling-Hammond, L. (2016). Global educational reform: Privatization vs. public investments in national education systems. New York, NY: Routledge.

Archer, D. (2016). Domestic tax and education. Background Paper for the Education Commission. http://report.educationcommission.org/resources/

Ayres, D. M. P. (1997). Tradition and modernity enmeshed: The educational crisis in Cambodia, 1953-1997. Doctoral dissertation, University of Sydney.

Ayres, D. (1999). Policymaking and policies of education in Cambodia. In D. Sloper (Eds.), Higher education in Cambodia: The social and educational context for reconstruction (pp. 51-65). UNESCO Principal Regional Office for Asia and the Pacific: Bangkok.

Ayres, D. M. (2000). Anatomy of a Crisis: Education, Development, and the State in Cambodia, 1953-1998. Honolulu, HI: University of Hawai'i Press.

Benveniste, L., Marshall, J., \& Araujo, M. C. (2008). Teaching in Cambodia. Washington, DC: World Bank.

Bilodeau, C., Pathammavong, S., \& Lê, Q. H. (1955). Compulsory education in Cambodia, Laos, and Viet-Nam. Paris, France: UNESCO.

Bray, M. (1996). Counting the full cost: Parental and community financing of education in East Asia. Washington D.C.: The World Bank in collaboration with UNICEF.

Bray, M. (1999a). The shadow education system: Private tutoring and its implications for planners. Paris: UNESCO International Institute for Educational Planning (IIEP).

Bray, M. (1999b). The private costs of public schooling: Household and community financing of primary education in Cambodia. Paris: UNESCO International Institute for Educational Planning (IIEP). 
Bray, M., \& Bunly, S. (2005). Balancing the books: Household financing of basic education in Cambodia. Hong Kong: Comparative Education Research Centre, The University of Hong Kong.

Bray, M., \& Kwo, O. (2013). Behind the façade of fee-free education: Shadow education and its implications for social justice. Oxford Review of Education, 39(4), 480-497.

Bray, M., Kobakhidze, M. N., Zhang, W., \& Liu, J. (2018). The hidden curriculum in a hidden marketplace: relationships and values in Cambodia's shadow education system. Journal of Curriculum Studies, 50(4), 435-455.

Bray M., Liu J., Zhang W., \& Kobakhidze M. N. (2019). (Mis)Trust and (Abuse of) Authority in Cambodian Education: Parallel Lessons in the Shadow. In: Schüpbach M., Lilla N. (eds) Extended Education from an International Comparative Point of View. Springer VS, Wiesbaden.

Brehm, W. (2017). The is and the ought of Knowing: Ontological Observations on Shadow Education Research in Cambodia. Southeast Asian Studies, 6(3), 485-503.

Brehm, W.C., Silova, I., \& Tuot, M. (2012). The public-private education system in Cambodia: The impact and implications of complementary tutoring. Budapest: Open Society Institute.

Brinkley, J. (2011). Cambodia's curse: The modern history of a troubled land. New York, NY: PublicAffairs.

Chandler, D. P. (1991). The land and people of Cambodia. New York, NY: Lippincott.

Chandler, D. (2008). A History of Cambodia, fourth edition. Chiang Mai, Thailand: Silkworm Books.

Clayton, T. (2000). Education and the politics of language: Hegemony and pragmatism in Cambodia, 1979-1989. Hong Kong: Comparative Education Research Centre, The University of Hong Kong.

Clayton, T. (2005). Re-orientations in moral education in Cambodia since 1975. Journal of Moral Education, 34(4), 505-517.

Dawson, W. (2009). The tricks of the teacher: Shadow education and corruption in Cambodia. In S. P. Heyneman (Ed.), Buying your way into heaven: Education and corruption in international perspective (pp. 51-74). Rotterdam, Netherlands: Sense Publishers. 
Dawson, W. (2011). "Supplementary Education in Cambodia." IIAS Newsletter (University of Leiden, International Institute for Asian Studies), 56:18-19. Available on-line: https://www.iias.asia/sites/default/files/theNewsletter/2019-06/IIAS_NL56_FULL.pdf

Deighton, L. C. (1971). Cambodia. In The Encyclopedia of Education (vol.1, p.578-584). Creswell-Collier Educational Corporation.

Duggan, S. J. (1996). Education, teacher training and prospects for economic recovery in Cambodia. Comparative Education, 32 (3): 361-375.

Dunnet, S. C. (1993) Cambodia, overcoming hardship, rebuilding its education system. WENR: World Education News and Reviews, 6(2), 20-23.

Dy, S. S. (2004). Strategies and policies for basic education in Cambodia: Historical perspectives. International Education Journal, 5(1), 90-97.

Ebihara, M. (1968). Svay, A Khmer Village in Cambodia. Unpublished Doctoral Dissertation submitted to Columbia University. New York: Columbia University.

Edwards, D. B. Jr., Le, H., \& Sustarsic, M. (2019): Spatializing a global education phenomenon: Private tutoring and mobility theory in Cambodia. Journal of Education Policy, DOI: 10.1080/02680939.2019.1610192

Engel, J. (2011). Rebuilding basic education in Cambodia: Establishing a more effective development partnership. Working paper for the Overseas Development Institute.

European Commission. (2012). Analysis of the continuous decline of MoEYS recurrent budget share in recent years. Presentation at the February 10, 2012 EDUCAM meeting. Phnom Penh, Cambodia.

Fergusson, L.C., \& Masson, G. (1997). A culture under siege: Post-colonial higher education and teacher education in Cambodia from 1953 to 1979. History of Education, 26(1), 91-112.

Haas, M. (1991a). Cambodia, Pol Pot, and the United States: The Faustian Pact. New York, NY: Praeger.

Haas, M. (1991b). Genocide by proxy: Cambodian pawn on a superpower chessboard. New York, NY: Praeger.

Hagai, S., Kitamura, Y., Khlok, V.R., Brehm, W.C. (2016). "Ideologies inside textbooks: Vietnamization and re-Khmerization of political education in Cambodia during the 1980s." In Jim Williams (Ed.) (Re)Constructing Memory: School and the Imagination of the Nation, Vol. 2 (pp. 49-73). Rotterdam: Sense Publishing. 
Hansen, A. R. (2007). How to behave: Buddhism and modernity in colonial Cambodia, 1860-1930. Honolulu: University of Hawai'i Press.

Hansen, A. R. (2011). "Modernism and morality in colonial Cambodia." In J. Marston (Ed.) Anthropology and community in Cambodia: Reflections on the work of May Ebihara (pp. 35-61). Melbourne, Australia: Monash University Press.

Kiernan, B. (1985). How Pol Pot came to power: Colonialism, nationalism, and communism in Cambodia, 1930-1975. New York: Verso.

Kobayashi, S. (2005). An ethnographic study on the reconstruction of Buddhist practice in two Cambodian temples: With the special reference to Buddhist Samay and Boran. Southeast Asian Studies, 42(4), 489-518.

Marshall, J. H., \& Fukao, T. (2019). Shadow education and inequality in lower secondary schooling in Cambodia: Understanding the dynamics of private tutoring participation and provision. Comparative Education Review, 63(1), 98-120.

Marston, J. (2011). Anthropology and community in Cambodia: Reflections on the work of May Ebihara. Melbourne, Australia: Monash University Press.

Menashy, F. (2019). International aid to education: Power dynamics in an era of partnership. New York: Teachers College Press.

MoEYS (2003). Education for All National Plan 2003-2015. Retrieved September17, 2019, from https://planipolis.iiep.unesco.org/sites/planipolis/files/ressources/cambodia_npa_efa_engl ish.pdf

MoEYS. (2007). Child friendly school policy. Phnom Penh.

NEP (2007). The impact of informal school fees on family expenditures. NGO Education Partnership, Education Operational Research.

Reimer, J. K. (2012) Local negotiation of globalised educational discourses: The case of child friendly schools in rural Cambodia. Unpublished PhD dissertation, The University of British Columbia, Vancouver.

Robertson, S. L., Mundy, K., Verger, A., \& Menashy, F. (2012). Public private partnerships in education: New actors and modes of governance in a globalizing world. Cheltenham, UK: Edward Elgar.

Ron Balsera, M., Klees, S.J., \& Archer, D. (2018). Financing education: why should tax justice be part of the solution?, Compare: A Journal of Comparative and International Education, 48(1), 147-162 
UNESCO. (1990). World declaration on education for all and framework for action to meet basic learning needs. Jomtien, Thailand: UNESCO. Retrieved from https://unesdoc.unesco.org/ark:/48223/pf0000127583

UNESCO. (2010). UNESCO National Education Support Strategy: Cambodia 2010-2013. Phnom Penh, Cambodia.

Verger, A., Novelli, M., \& Altinyelken, H. K. (Eds.). (2012). Global education policy and international development: New agendas, issues and policies. New York: Bloomsbury.

Whitaker, D. (1973) Area handbook for the Khmer Republic (Cambodia). Washington, DC: US Government Printing Office.

Windham, D. (1992). Education for all: The requirements - Roundtable themes III, World conference on education for all, Jomtien, Thailand. Paris: UNESCO.

Zhao, Y. (2018). What works may hurt: Side effects in education. New York, NY: Teachers College Press. 